\title{
Spatio-Temporal Dynamics of Glossinidae, Tabanidae and Stomoxyidae Around the Douala-Edea Wildlife Reserve in Cameroon
}

\author{
Hiol Victor1, Sieumeni Andre Djonguep², Mamoudou Abdoulmoumini ${ }^{1,}$ *, Sevidzem Silas Lendzele ${ }^{3}$, \\ Njan-Nloga Alexandre Michel $^{2}$, Nukenine Elias Nchiwan ${ }^{2}$ \\ ${ }^{1}$ Department of Parasitology and Parasitological Diseases, School of Veterinary Medicine and Science, University of Ngaoundéré, \\ Ngaoundéré, Cameroon \\ ${ }^{2}$ Department of Biological Sciences, University of Ngaoundere, Ngaoundere, Cameroon \\ ${ }^{3}$ Ecole Doctorale des Grandes Ecoles (EDGE), Laboratoire d'Ecologie Vectorielle (LEV-IRET), Libreville, Gabon
}

\section{Email address:}

mamoudou.abdoulmoumini@yahoo.fr (M. Abdoulmoumini)

${ }^{*}$ Corresponding author

\section{To cite this article:}

Hiol Victor, Sieumeni Andre Djonguep, Mamoudou Abdoulmoumini, Sevidzem Silas Lendzele, Njan-Nloga Alexandre Michel, Nukenine Elias Nchiwan. Spatio-Temporal Dynamics of Glossinidae, Tabanidae and Stomoxyidae Around the Douala-Edea Wildlife Reserve in Cameroon. American Journal of Entomology. Vol. 3, No. 2, 2019, pp. 36-42. doi: 10.11648/j.aje.20190302.12

Received: March 12, 2018; Accepted: March 27, 2018; Published: June 13, 2019

\begin{abstract}
The objective of this work was to evaluate the diversity and composition of glossines, tabanids and stomoxes in the dry and rainy seasons at the Douala-Edéa Game Reserve (DEGR) using Biconical, Vavoua and Nzi traps. Three traps i.e. one of each type was pitched in the sampled sites with collection carried out three days per month from January to May 2017. A total of 1028 flies were caught among which $49.61 \%$ of them belonged to the family Stomoxyidae, Tabanidae (34.63\%) and Glossinidae (15.76\%). Fourteen species were caught and grouped under the following genera: Glossina (02), Stomoxys (04), but Tabanidae was represented by three genera: Tabanus consisting of three species, Chrysops (03) and Haematopota (2) with the genus Tabanus highly represented. Glossina, Stomoxys and Chrysops were abundant in the rainy season while Tabanus and Haematopota were abundant in the dry season. $50.88 \%$ of the catches were from the Vavoua trap, followed by Nzi (39.3\%) and Biconical (9.2\%).
\end{abstract}

Keywords: Dynamics, Season, Traps, Game Reserve, Douala-Edéa

\section{Introduction}

The use of traps in the survey and control of hematophagous flies such as tsetse flies, stomoxes and tabanids is a cheap and environmentally friendly approach that results in a high sample representation in a population than net catches [1]. Blood-sucking insects are pest of man, domestic and wild animals. Glossines, tabanids and stomoxes for instance play an extremely important role in human and animal health [2]. Indeed, these insects because of their hematophagous habits represent a scourge both by their direct nuisance [3] and as vectors (mechanical or biological) of various pathogens $[4,5]$. These insects are involved in the biological and/or mechanical transmission of many diseases, including African trypanosomoses (human and animal), loa loa filariasis, rift valley fever, bovine anaplasmosis, African swine fever, and equine infectious anemia etc. [6, 7].

Several studies have focused on the ecological diversity of hematophagous flies and the efficacy of different traps for their survey and control in West and Central Africa [8, 9, 10, 11]. This can be explained by the threat posed by African trypanosomiasis (human and animal) and its vectors. Most of these previous works are old and perhaps no longer correspond to the current reality and need to be updated while information in other regions like the case of the Littoral zone of Cameroon is still lacking. Because of the current lack of information about Glossinidae, Tabanidae and Stomoxyidae fauna of the Littoral region of Cameroon, the 
present entomological survey was designed to study their species composition, abundance as well as their diurnal activity rhythms around the DEGR in order to declare the site as being conducive for ecotourism as well as provide baseline data for future anti-vectorial activities.

\section{Material and Methods}

\subsection{Study Sites}

The DEGR is located in the Littoral region precisely in the Sanaga Maritime zone in the Wouri division of Cameroon. Geographically, it falls between Latitude $3^{\circ} 14^{\prime}$ and $3^{\circ} 50^{\prime}$ North and Longitude $9^{\circ} 34^{\prime}-10^{\circ} 03^{\prime}$ East [12] (figure 1). It has a surface area of about $1,600 \mathrm{~km}^{2}$. Located on the coastal plain, it extends from the Atlantic coast to a maximum distance of $35 \mathrm{~km}$ with its eastern limit along the river
Dipombe. The Reserve is made up of two unequal parts: the largest part located in the South between the mouths of Sanaga to the North and Nyong to the South; the other remaining part extends along the northern coast of Sanaga to the tip of Souelaba and is bordered to the east by the Kwa Kwa Creek [13]. This area consists of several villages as well as wild animals (potential hosts of blood-sucking flies). Some of the wild animals of this area are-Loxodonta africanus (African elephant), Pan troglodytes (chimpanzee), Tragelaphus spekei (antelope) of the African forest, Cercopithecus mona (African monkey), Atherurus africanus (porcupine), wild Suidae (hylcherry), manatee, giant pangolin and other rodents and reptiles (snakes, crocodiles, monitor lizards, turtles...). The avian fauna consists of an impressive variety of endemic birds that attract many western researchers and tourists [14].

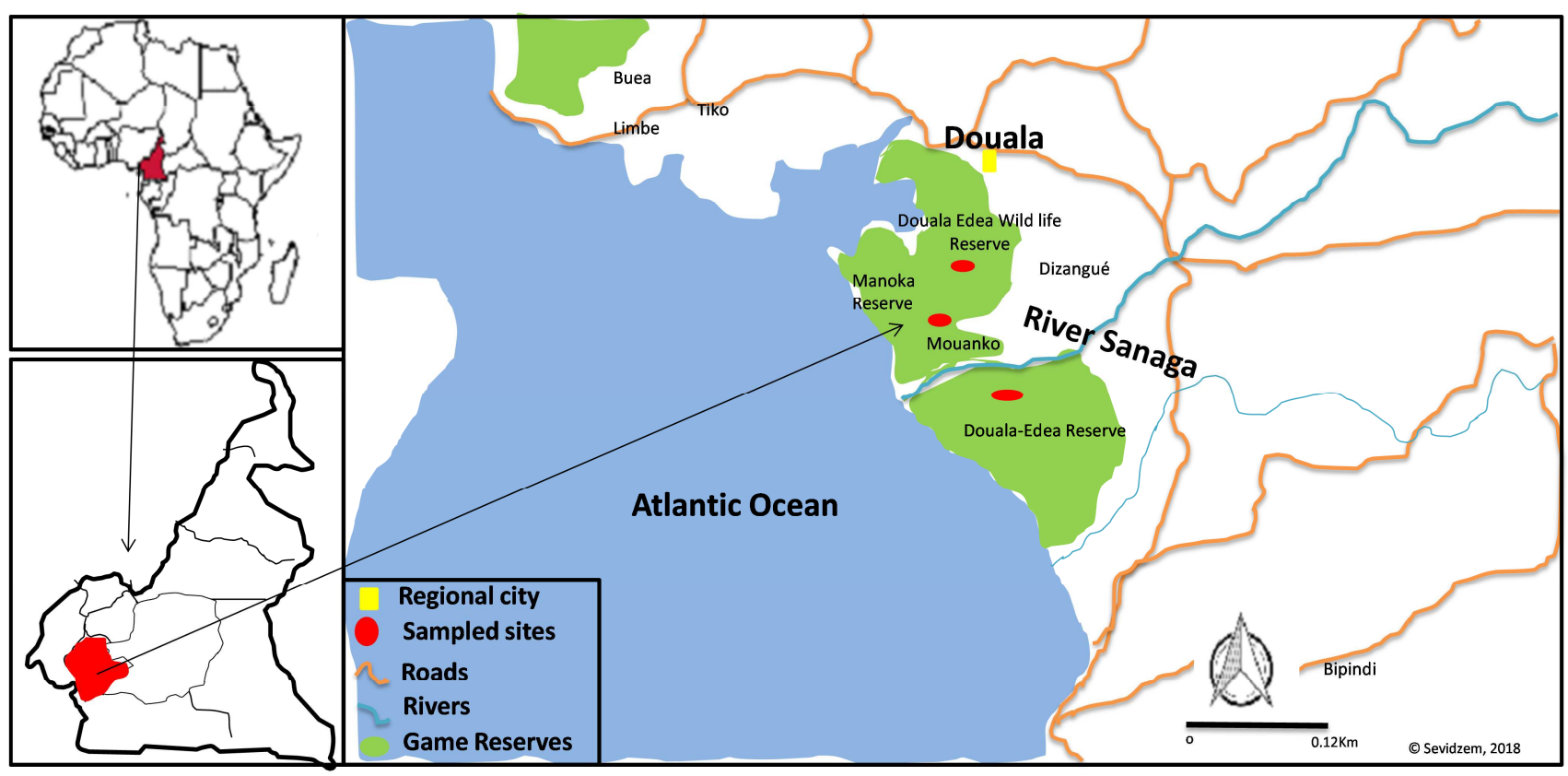

Figure 1. Map of the study area.

\subsection{Entomological Prospection}

The entomological survey was conducted from January to May 2017 for a period of five months, with collections made three days per month. The months of January and February represented the dry season, March was a transition month (from dry season to rainy season) while April and May represented the rainy season. The three different traps (Biconical, Vavoua and Nzi) were away from each other by a distance of 200m [15]. Trapping commenced between 6 a.m. and 6:30 a.m. Flies were collected every two hours i.e. 6-8h, $8-10 \mathrm{~h}, 10-12 \mathrm{~h}, 12-14 \mathrm{~h}, 14-16 \mathrm{~h}$ and $16-18 \mathrm{~h}$. Tsetse flies identification was carried out using the identification and teaching software developed in 1998 by the French Institute of Scientific Research for Development (IRD) in collaboration with the Center for International Cooperation in Agricultural Research for Development (CIRAD). The key of Zumpt [16] and Garros [17] were used for stomoxes identification. The morphological key of Surcouf and Ricardo [18] was used for tabanid identification.

\subsection{Data Analysis}

The abundance of hematophagous flies was defined as the apparent density (ADT), expressed as the number of flies captured per trap and day. It is a very important indicator of the probable risk of contact with hematophagous flies. All the statistical analyses were carried out using the SPSS software (version 11.0). The Chi-square test was used to compare the catches with site and trap types.

\section{Results}

A total of 1028 blood-sucking flies were caught and identified into three families. The numbers, apparent densities (ADTs) and proportions based on the different fly families are presented in Table 1 . There was a statistically 
significant difference $(\mathrm{P}<0.005)$ in the proportion of the individuals caught at family level with respect to season (Table 2 .

Table 1. Composition of the various insects caught by family.

\begin{tabular}{llll}
\hline Family & Number & Proportion (\%) & ADT (f/t/d) \\
\hline Glossinidae & 162 & 15.76 & 3.60 \\
Stomoxyidae & 510 & 49.61 & 11.33 \\
Tabanidae & 356 & 34.63 & 7.91 \\
Total & 1028 & 100 & 22.84 \\
\hline
\end{tabular}

$\mathrm{AD}$, apparent density, $\mathrm{f} / \mathrm{t} / \mathrm{d}$ flies per trap and day

Table 2. Distribution of families with respect to season.

\begin{tabular}{lllll}
\hline & Season & & Total & $\boldsymbol{X}^{2}, \boldsymbol{P}$ and $\boldsymbol{d} \boldsymbol{f}$ \\
\hline Family & Dry $[\mathrm{n}(\%)]$ & Rainy $[\mathrm{n}(\%)]$ & & \\
Glossinidae & $33(26.60)$ & $91(73.40)$ & 124 & $\mathrm{X}^{2}=173.433$ \\
Stomoxyidae & $145(32.50)$ & $301(67.50)$ & 446 & $\mathrm{P}<0.005$ \\
Tabanidae & $242(77.30)$ & $71(22.70)$ & 313 & $\mathrm{df}=2$ \\
Total & $420(47.60)$ & $463(52.40)$ & 883 & \\
\hline
\end{tabular}

P, probability level; $d f$, degree of freedom; n, number; $X^{2}$ chi square

\subsection{Species Composition}

162 tsetse flies were collected and identified as G. palpalis (79.01\%) and G. fuscipes (20.99\%). 510 stomoxes were identified as $S$. n. niger (37.84\%), S. omega (45.01\%), $S$. xanthomelas $(11.37 \%)$ and $S$. calcitrans $(5.69 \%)$. The tabanids caught belonged to three genera i.e. Tabanus $[T$. taeniola (54.81\%), T. par (43.91\%) and T. socius (1.28\%)], Chrysops [C. longicornis $(88.57 \%)$, C. silacea $(8.57 \%)$ and C. dimidiate (2.86\%)]. Haematopota was represented by $H$. decora (66.67\%) and Haematopota sp (33.33\%).

\subsection{Seasonal Variations in Fly-Catches}

The maximum catches were observed in the rainy season (April-May) and scanty record was noticed in the dry season (January-February) (Table 3).

Table 3. Seasonal Variations of flies.

\begin{tabular}{llll}
\hline Species & Dry season & Rainy season & $\mathbf{P}, \boldsymbol{X}^{2}$ and df \\
\hline G. palpalis & 26 & 75 & $\mathrm{P}=0.646$ \\
G. fuscipes & 7 & 16 & $\mathrm{X}^{2}=0.211$ \\
Total glossines & $33(26.61 \%)$ & $91(73.39 \%)$ & $\mathrm{df}=1$ \\
S. n. niger & 42 & 119 & \\
S. omega & 67 & 134 & $\mathrm{P}<0.001$ \\
S. xanthomelas & 16 & 39 & $\mathrm{X}^{2}=20.94$ \\
S. calcitrans & 20 & 9 & $\mathrm{df}=3$ \\
Total stomoxyines & $145(32.51 \%)$ & $301(67.49 \%)$ & \\
T. taeniola & 101 & 40 & $\mathrm{P}<0.001$ \\
T. par & 128 & 7 & $\mathrm{X}^{2}=141.34$ \\
T. socius & 4 & 0 & $\mathrm{df}=7$ \\
Total Tabanus & $233(83.21 \%)$ & $47(16.79 \%)$ & \\
\hline
\end{tabular}

\begin{tabular}{llll}
\hline Species & Dry season & Rainy season & $\mathbf{P}, \boldsymbol{X}^{2}$ and df \\
\hline C. longicornis & 0 & 20 & $\mathrm{P}<0.001$ \\
C. dimidiata & 0 & 1 & $\mathrm{X}^{2}=141.34$ \\
C. silacea & 0 & 3 & $\mathrm{df}=7$ \\
Total Chrysops & 0 & $24(100 \%)$ & \\
H. decora & 6 & 0 & \\
Haematopota sp. & 3 & 0 & \\
Total Haematopota & $9(100 \%)$ & 0 & \\
\hline
\end{tabular}

P, probability level, df, degree of freedom, $X^{2}$-chi square

\subsection{Monthly ADT of Flies Caught in the Study Area}

The ADT of the various species of flies caught varied with the prospection months. For glossines, their highest abundance was recorded during the month of May. Stomoxes abundance occurred during the month of February and April. While tabanids abundance was noticed in the month of January and February (Table 4).

Table 4. Month apparent densities of glossines, stomoxes and tabanids.

\begin{tabular}{llllll}
\hline Species & January & February & March & April & May \\
\hline G. palpalis & 1.89 & 1.00 & 3.00 & 3.78 & 4.55 \\
G. fuscipes & 0.55 & 0.22 & 1.22 & 1.22 & 0.55 \\
Total glossines & 2.44 & 1.22 & 4.22 & 5.00 & 5.11 \\
S. . niger & 0.89 & 3.78 & 3.55 & 2.11 & 11.11 \\
S. omega & 5.00 & 2.44 & 3.22 & 5.44 & 9.44 \\
S. xanthomelas & 0.78 & 1.00 & 0.33 & 1.22 & 3.11 \\
S. calcitrans & 0.44 & 1.78 & 0.00 & 0.22 & 0.78 \\
Total stomoxyins & 7.11 & 9.00 & 7.11 & 9.00 & 24.44 \\
T. taeniola & 2.33 & 8.89 & 3.33 & 1.78 & 2.67 \\
T. par & 12.33 & 1.89 & 0.22 & 0.67 & 0.11 \\
T. socius & 0.44 & 0.00 & 0.00 & 0.00 & 0.00 \\
C. longicornis & 0.00 & 0.00 & 1.22 & 1.33 & 0.89 \\
C. dimidiata & 0.00 & 0.00 & 0.00 & 0.11 & 0.00 \\
C. silacea & 0.00 & 0.00 & 0.00 & 0.33 & 0.00 \\
H. decora & 0.00 & 0.67 & 0.00 & 0.00 & 0.00 \\
H. sp. & 0.00 & 0.33 & 0.00 & 0.00 & 0.00 \\
Total tabanids & 15.11 & 10.78 & 4.78 & 4.22 & 3.66 \\
\hline
\end{tabular}

\subsection{Daily Activity Patterns of the Various Families of Flies}

The diurnal activity rhythm of glossines was biphasic with one peak occurring in the morning and the other in the late evening in the rainy season. On the contrary the activity pattern in the dry season was monophasic with one peak occurring only in the late evening (Figure 2). The diurnal activity pattern of stomoxes in the study area was bimodal in both seasons with one peak occurring in the early morning and another occurring late in the evening (Figure 3). The daily activity of tabanids was unimodal (10h-12h) in the dry and rainy seasons (Figure 4). 


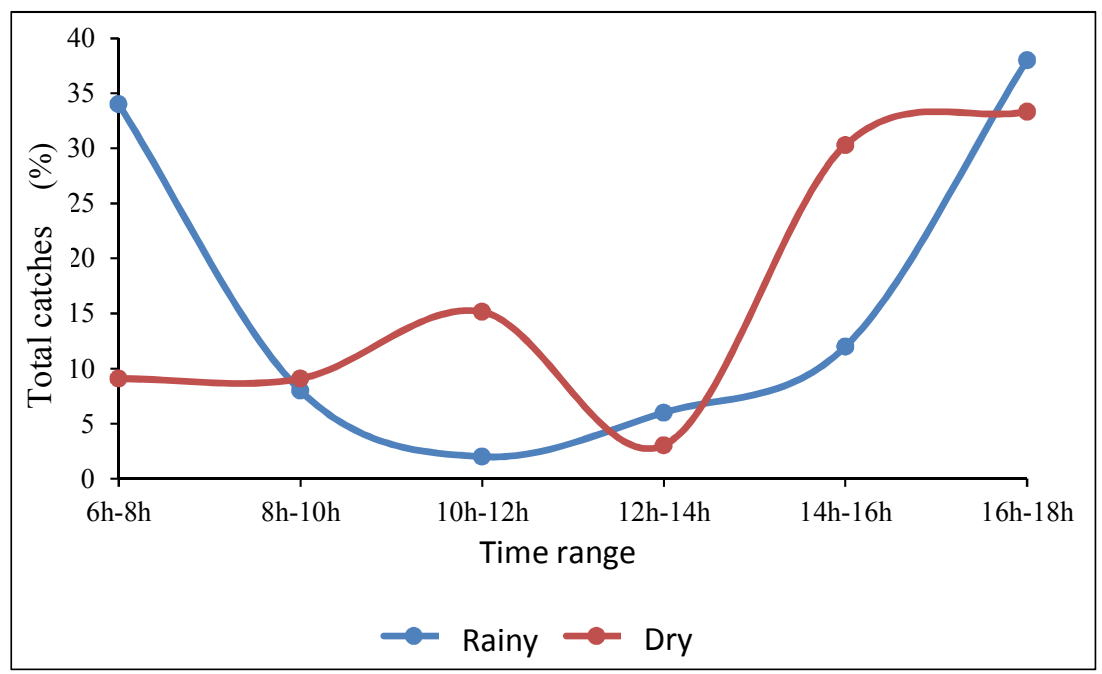

Figure 2. Daily activity rhythms of glossines in the rainy and dry seasons.

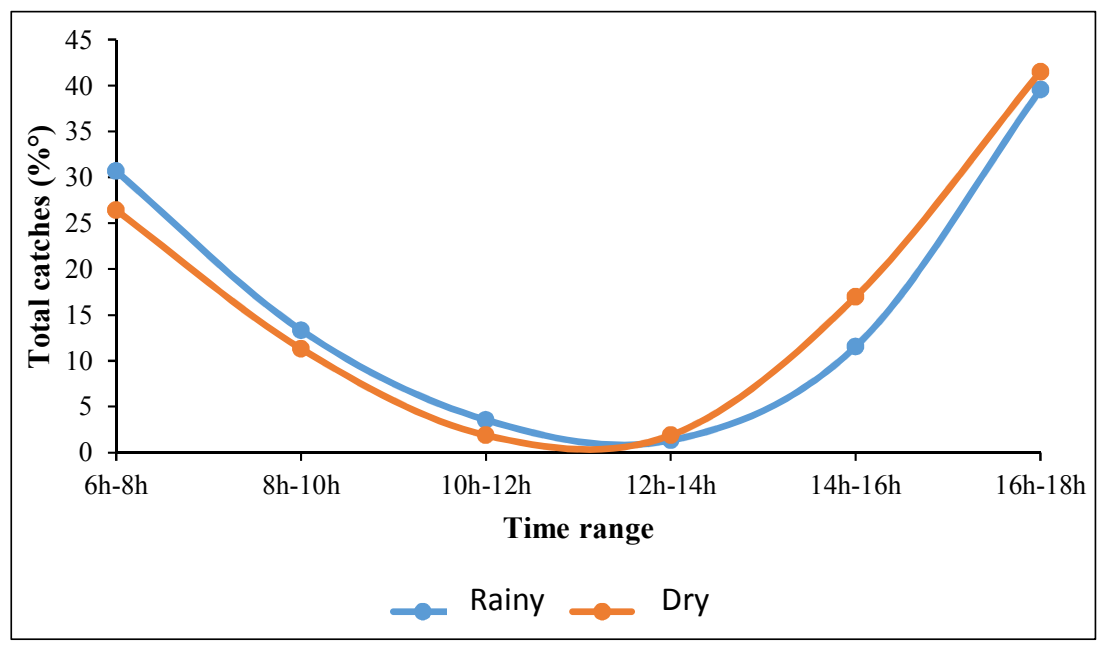

Figure 3. Daily activity rhythm of stomoxes in the rainy and dry seasons.

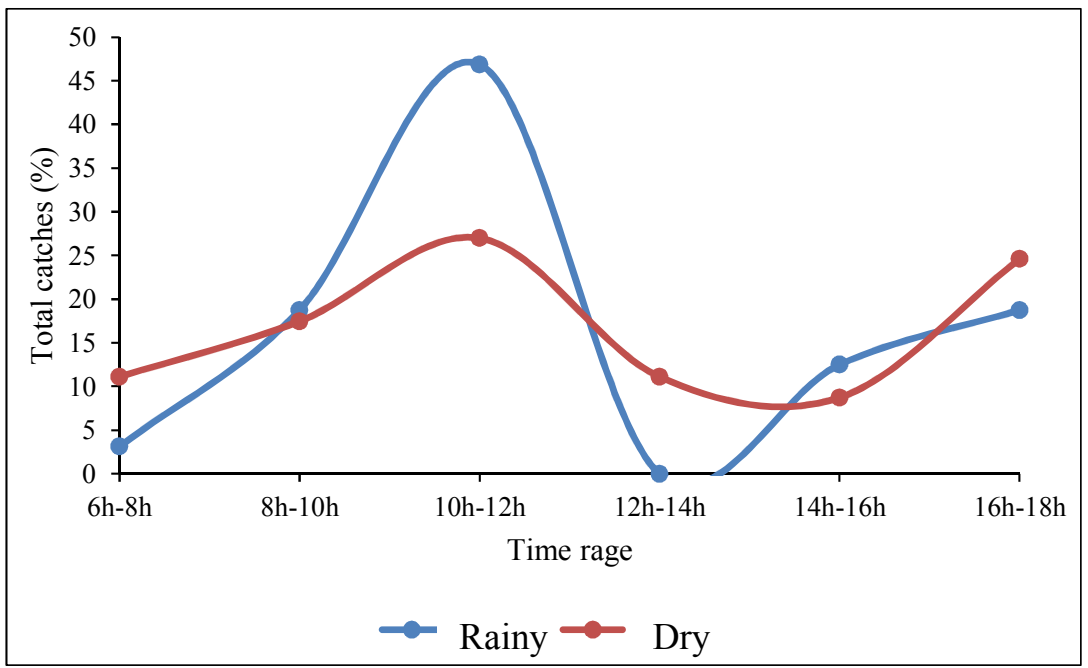

Figure 4. Daily activity of tabanids in the rainy and dry seasons.

\subsection{Species-Specific Preference of the Different Trapping Systems Used in the Survey}

The different types of traps used in this study captured the various species of the families in different proportions in the different seasons (Table 5, Table 6). 
Table 5. Comparison of catches glossines, stomoxyines and tabanids from the different traps.

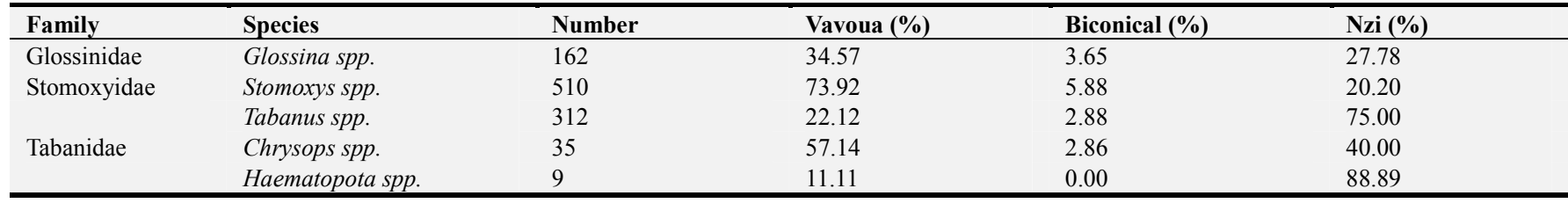

Table 6. Efficacy of trap-types with respect to season.

\begin{tabular}{|c|c|c|c|c|c|}
\hline \multirow{2}{*}{ Family } & \multirow{2}{*}{ Trap-types } & \multicolumn{2}{|l|}{ Season } & \multirow{2}{*}{ Total } & \multirow{2}{*}{$X^{2}, P$ and $d f$} \\
\hline & & Dry [n (\%)] & Rainy [n (\%)] & & \\
\hline \multirow{4}{*}{ Glossinidae } & Biconical & $12(24.50)$ & $37(75.50)$ & 49 & \multirow{4}{*}{$\begin{array}{l}X^{2}=0.418 \\
P=0.811 \\
d f=2\end{array}$} \\
\hline & $\mathrm{Nzi}$ & $11(30.60)$ & $25(69.40)$ & 36 & \\
\hline & Vavoua & $10(25.60)$ & $29(74.40)$ & 39 & \\
\hline & Total & $33(26.60)$ & $91(73.40)$ & 124 & \\
\hline \multirow{3}{*}{ Stomoxyinae } & Biconical & $8(32.00)$ & $17(68.00)$ & 25 & \multirow{3}{*}{$\begin{array}{l}X^{2}=4.564 \\
P=0.102 \\
d f=2\end{array}$} \\
\hline & Nzi & $20(23.00)$ & $67(77.00)$ & 87 & \\
\hline & Total & $145(32.50)$ & $301(67.50)$ & 446 & \\
\hline \multirow{4}{*}{ Tabanidae } & Biconical & $6(66.70)$ & $3(33.30)$ & 9 & \multirow{5}{*}{$\begin{array}{l}X^{2}=16.378 \\
P<0.005 \\
d f=2\end{array}$} \\
\hline & Nzi & $191(83.00)$ & $39(17.00)$ & 230 & \\
\hline & Vavoua & $45(60.80)$ & $29(39.20)$ & 74 & \\
\hline & Total & $242(77.30)$ & $71(22.70)$ & 313 & \\
\hline Total & & $242(77.30)$ & $71(22.70)$ & & \\
\hline
\end{tabular}

P, probability level; df, degree of freedom; n, number; $X^{2}$ chi square

\section{Discussion}

The results of this study indicated the presence of two species of tsetse flies namely Glossina palpalis and Glossina fuscipes. Although Rageau [19] reported three species notably G. caliginea, G. fusca and G. tabaniformis for Cameroon. These three species are zoophilic and forestrestricted [19]. The absence of G. caliginea and $G$. tabaniformis can be explained by the current destruction of forests, the scarcity of game around villages, human encroachment of forests and climate change [20]. The glossines fauna of the Soudano-sahelian and Soudanoguinean regions of Cameroon is different from that of the dense forest of Cameroon. The survey of Sevidzem et al., [21] led to the identification of two species of glossines notably Glossina morsitans (savanna-type) and Glossina tachinoides (riverine-type). These species were not captured in the present study in the forest of the Sanaga maritime area and it shows that they are only dorminant in savanna areas with rivers. On the contrary the species of glossines caught during the survey were typically forest species and vectors of human and animal trypanosomes [22].

The genus Stomoxys is represented by four species and indicate a high diversity of the Stomoxyinae fauna of this area. In Ivory Coast, Acapovi [8] reported two species and in Gabon, Zinga [9] reported the presence of three species around parks. In the Adamaoua plateau of Cameroon, Sevidzem et al., [13] signaled the presence of stomoxes at the livestock-wildlife interface in the Faro division. The pasture area of North Cameroon is also infested with stomoxes [21]. Stomoxes accounted for almost half of the catches probably because of the environmental conditions of this region that favored their development and survival. Stomoxes can feed on wildlife [23] and are also attracted to livestock [24]. It was interesting to know that two species of stomoxes (S. omega and $S$. xanthomelas) captured during the survey did not appear in the collections of Sevidzem et al., [21]. The survey of Sevidzem et al., [21] was conducted in the dry season in the savanna region of North Cameroon for few days as compared to this current study that was conducted for five months in two seasons in the forest of the littoral zone of Cameroon. These differences in trapping duration and localities can be responsible for the differences in the species composition in the different environments. Mavoungou et al., [2] reported that $S$. calcitrans and $S$. n. niger were both zoophilic and anthropophilic.

The present entomological prospection revealed that the genus Tabanus was dominant in the collection, followed by Chrysops, Haematopota and Ancala. The absence of certain genera and species could be related to the limited sampling sites, number/types of traps used. Sevidzem et al., [25] identified six species of the family Tabanidae during their survey in the Sora Mboum type-locality of North Cameroon amongst these species $T$. socius was not present but it was trapped in this present survey. C. dimidiata and C. silacea are two important biological vectors of loa loa filariasis that has already been reported in the Southern Cameroon rain forests precisely in the Lekie division by Demanou et al., [26]. These two species of Chrysops were dorminant in the present collections but were morphologically different from $C$. longicornis and C. distinctipennis which are important loasis biological vectors, but they are savanna species. C. distinctipennis was signaled in the Sahel-savanna of North Cameroon for the first time by Sevidzem et al., [25]. The genus Haematopota, collected during this present study was not reported in the previous studies of Cameroon [27, 25, 28, 29].

The peak tsetse abundance was observed in May (rainy 
season) possibly because the weather conditions during this month were favorable for them. February was characterized by few tsetse flies and can be due to the high temperatures which did not favour their development and activities [30]. There were more stomoxes in the rainy season, but their numbers reduced greatly in the dry season. The stomoxes rest under vegetation during hot weather. It was noticed that the rainy season offered favorable conditions for stomoxes reproduction and longevity [31]. This observation agrees with the report of Bouyer et al., [3] that stomoxes make fictitious appearances in the early morning and in the evening and that their apparent densities were strongly influenced by season.

Seasonal variation of tabanids was genera-dependent. The genus Tabanus was present in all seasons. The peak abundance of T. par occurred in January (dry season) and decreased gradually in the rainy season without ever disappearing completely throughout the survey period. A similar monthly pattern in catches was recorded with $T$. taeniola except that their peak occurred in February. Climatic conditions, vegetation (presence of nectar) and fauna seem to influence the abundance of tabanids across seasons [8]. In the forest, the activity of tabanids was unimodal with peak in the evening and this same pattern occurred in both seasons. This present result was contrary to the report of Zinga [9] that the activity of tabanids was bimodal, but corroborates with that of Solano et al., [32] for tsetse flies where their peak was unimodal with a greater proportion collected during the hottest hours of the day at the edge of streams.

Stomoxes had a bimodal daily activity pattern. This finding was like that of most researchers [8, 33, 9]. The abundance peak of stomoxes was higher in the evening as compared to the morning and this is a common pattern for most dipterans.

Based on the trapping systems used in this survey, it was observed that the Nzi trap was sensitive to individuals of the family Tabanidae and the Vavoua trap caught more stomoxes. The Biconical trap on the other hand recorded high catches of glossines. This finding corroborates with that of Desquesnes [5]. The Vavoua trap is known to be effective in the survey of tabanids and muscids in North and Central South-Western (Campo) parts of Cameroon [21, 25, 28]. However, their efficacy depends on their placement and season of the survey.

\section{Conclusion}

This study constitutes a preliminary work on the species composition and dynamics of tsetse, stomoxes and tabanids around the Douala Edea Game Reserve. This work allowed us to establish a list of hematophagous flies present in this site. This list may serve as the basis for future studies. Knowledge about blood-sucking insects is an important element in vector control as these insects pose a high risk to human and animal health. The guide for a successful antivectorial program the mastery of the distribution and ecology of the target vector population.

\section{Acknowledgements}

This work was carried out thanks to the institutional and logistic support of the Department of parasitology and parasitic diseases of the School of Veterinary Medicine and Sciences of the University of Ngaoundere as well as the field station laboratory of the University of Tübingen in Ngaoundere.

\section{Conflict of Interest}

All the authors do not have any possible conflicts of interest.

\section{References}

[1] A. Challier and C. Laveissiere. (1973). Un nouveau piège pour la capture des glossines (Glossina: Diptera, Muscidae); description et essais sur le terrain. Cahier. ORSTOM, Série Entomologie Médicale et Parasitologie. Pp 12.

[2] J. F. Mavoungou, P. Jay-Robert, J. Gilles, E. A. Atsame, G. Duvallet. (2008). Ecologie des stomoxes (Diptera: Muscidae) au Gabon. Premier inventaire dans différentes zones écologiques. Parasite. Pp 8.

[3] J. Bouyer, Y. Grimaud, M. Pannequin, O. Esmault, M. Desquesnes. (2012). Importance épidémiologique et contrôle des stomoxes à la réunion. Bulletin épidémiologique, santé animale et alimentation $\mathrm{n}^{\circ}$ 43/ spécial DOM-TOM. Pp 6.

[4] F. Baldacchino, V. Muenworn, M. Desquesnes, F. Desoli, T. Charoenviriyaphap, G. Duvallet. (2013). Transmission of pathogens by Stomoxys flies (Diptera, Muscidae): a review. Parasite. Pp. 13.

[5] M. Desquesnes, M. L. Dia, G. L. Acapovi, W. Yoni, L. Foil, R. Pin. (2005). Les vecteurs mécaniques des trypanosomoses animales: Généralités, morphologie, biologie, impacts et contrôle. Identification des espèces les plus abondantes en Afrique de l'Ouest. Bobo-Dioulasso, Burkina Faso, Editions Cirdes. Pp 68.

[6] E. Salou, J. B. Rayaisse, C. Laveissiere, A. Sanon, P. Solano. (2012). Interactions comportementales et rythmes d'activité de Glossina palpalis gambiensis et $G$. tachinoides (Diptera: Glossinidae) en galerie forestière au Burkina Faso. Parasite. Pp 9.

[7] F. Baldacchino, M. Desquesnes, S. Mihok, L. D. Foil, G. Duvallet, S. Jittapalapong. (2014). Tabanids: Neglected subjects of research, but important vectors of disease agents Infection, Genetics and Evolution (Article in press).

[8] G. L. Acapovi-yao. (2005). Identification et bioécologie des Tabanidés, vecteurs mécaniques potentiels de la transmission de la trypanosomose bovine dans les régions de savanes en Côte-d'Ivoire (Odienné et Korhogo). Thèse de Doctorat, Université de Cocody, Abidjan Côte-d'Ivoire, Pp 162.

[9] C. R. Zinga-Koumba. (2016). Ecologie des mouches piqueuses (Stomoxes, Tabanidés et Glossines) dans deux parcs nationaux du Gabon (Ivindo et Moukalaba Doudou). Thèse de Doctorat. Ecole Régionale Post-universitaire d'aménagement et de gestion intégrés des forêts et territoires tropicaux. Université de Kinshasa. République démocratique du Congo. Pp. 301. 
[10] S. L. Sevidzem, A. Mamoudou, A. F. Woudamyata, P. A. Zoli. (2015). Contribution to the knowledge of ecodiversity and density of tsetse (Glossinidae) and other biting flies (Tabanidae and (Stomoxyinae) in the fly controlled-infested livestock/wild life interface of the Adamawa plateau Cameroon. Journal of Entomology and Zoology Studies. Pp 5.

[11] A. Mamoudou, S. L. Sevidzem, J. M. Feussom and M. Abdoulay. (2017). Deltamethrin Coated Screen against Tsetse and Trypanosomosis, Agricultural Technology and Biological Sciences Walailak Journal of Science and Technology, 14 (11): 893-909.

[12] Din. (2001). Mangrove du Cameroun, statut écologique et perspective de gestion durable. Thèse d'Etat, université de Yaoundé I. Cameroun. Pp 268.

[13] CWCS. (2001). CWCS Douala-Edea forest project. Report of activities/ rapport d'activité 2000. Cameroon Wildlife conservation society, Mouanko. Pp 40.

[14] CWCS. (2006). CWCS Douala-Edea forest project. Report of activities/ rapport d'activité 2005. Cameroon Wildlife conservation society, Mouanko. Pp 42.

[15] S. Mihok, D. A. Carlson, E. S. Krafsur, L. D. Foil. (2006). Performance of the Nzi and other traps for biting flies in North America. Bulletin of Entomological Research. Pp 11.

[16] F. Zumpt. (1973). The Stomoxyinae biting flies of the world. Taxonomy, biology, economic importance and control measures. Gustav Fischer Verlag, Stuttgart. Pp 175.

[17] C. Garros, J. Gilles, G. Duvallet. (2004). Un nouveau caractère morphologique pour distinguer Stomoxys calcitrans et $S$. niger (Diptera: Muscidae). Comparaison de populations de l'île de La Réunion. Parasite. Pp 4.

[18] J. M. Surcouf, G. Ricardo. (1909). Etude monographique des tabanides d'Afrique. Ed. Masson et Cie (Paris). Pp. 292.

[19] J. Rageau. (1951). Tsé-tsé et végétation des glossines au Cameroun Français. Bulletin of the Exotic Pathology Society, Pp 5.

[20] I. Morlais. (1998). Identification des trypanosomes chez les glossines en zones endemiques de trypanosomose humaine au Cameroun. Thèse de Doctorat, Université de Montpellier II. Pp 229.

[21] S. L. Sevidzem, A. Mamoudou, G. L. Acapovi-Yao, M. Achiri, T. Tchuinkam, K. C. R. Zinga, J. F. Mavoungou. (2016). First Inventory of non-biting and Biting Mucids of North Cameroon. International Research Journal of Biological Sciences, 5 (10), 12-20.

[22] G. Acapovi-Yao, K. Allou, J. F. Mavoungou, D. Zoh, M. L. Dia, K. E. N'goran. (2013). Geographical distribution and Trypanosoma infection of Glossina palpalis palpalis (Diptera, Glossinidae) in the relics of the forest and the city of Abidjan-
Ivory Coast. Revue Africaine de Santé et de Productions Animales. 11 (1).

[23] S. Mihok and PH Clausen. (1996). Feeding habits of Stomoxys spp. Stable flies in a Kenyan forest. Medical and Veterinary Entomology, (10): 392-394.

[24] L. D. Foil and J. A. Hogsette. (1994). Biology and control of tabanids, stable flies and horn flies. Review of Science and Technology, Office of International Epizootics, Pp 34.

[25] S. L. Sevidzem, M. Abdoulmoumini, A. Y. G. Lydie. (2017). Spatial Repartition of Tabanids (Diptera: Tabanidae) in Different Ecological Zones of North Cameroon. Biodiversity International Journal. 1 (2): 00010.

[26] M. Demanou, S. D. S. Pion, M. Boussinesq. (2001). Etude entomologique sur la transmission de la loase dans le department de la Lékie (Cameroun). Entomologie Medicale: Bulletin of the Exotic Pathology Society, 94: 347-352.

[27] M. T. Mbanwei. (2016). Population structure of mechanical vectors (Tabanids) of trypanosomosis and the optimisation of PCR conditions for tabanids blood meal analysis in the Far North Region of Cameroon. Thesis of Doctorat in veterinary medicine. Ecole des Sciences et de Médecine Vétérinaire de l'Université de N'gaoundéré, Cameroun. Pp 112.

[28] F. Mounioko, J. F. Mavoungou, C. R Zinga-Koumba, P. E. Engo, A. A. Kumba, A. P Maroundou, E. N, J. L Tamesse, G. Simo, B. M'batchi. 2017. Etude Préliminaire des vecteurs Mécaniques des trypanosomes dans la localité de Campo et ses environs (Sud-Ouest du Cameroon). Faunistic Entomology. 70: 95-105.

[29] E. S. Eteme, A. M. Njan Nloga, S. Abah, E. Ngo Bum. (2017). The Dynamics of Tsetse Flies Around the Mbam and Djerem National Park. Journal of Diseases and Medicinal Plants, 3 (3): 58-64.

[30] V. Codja. (1981). Trypanotolérance et immunité: Recherches sur les taurins de la République Populaire du Bénin, Thèse pour obtenir le grade de Docteur vétérinaire, soutenue à Dakar, Sénégal. Pp 80.

[31] A. Salem. (2012). Stomoxys calcitrans (L. 1758): morphologie, biologie, rôle vecteur et moyen de lutte. Thèse de Doctorat de l'Université de Toulouse France. Pp 149.

[32] P. Solano, D. Kaba, S. Ravel, N. Dyer, B. Sall, M. J. B. Vreysen, M. T. Seck, H. Darbyshir, L. Gardes, M. J. Donnelly, T. de Meeûs, J. Bouyer. (2010). Tsetse population genetics as a tool to choose between suppression and elimination: the case of the Niayes area in Senegal. PLoS Neglected Tropical Diseases, 4, e692.

[33] Y. Grimaud. (2013). Les stomoxes (DIPTERA: MUSCIDAE) à l'île de la Réunion: biologie, écologie et moyen de lutte. Groupement de la défense sanitaire de la Réunion. Pp 8. 